\title{
Employee Green Performance of Job: A Systematic Attempt towards Measurement
}

\author{
A. Anton Arulrajah \\ Senior Lecturer \\ Eastern University, Sri Lanka \\ H.H.D.N.P. Opatha \\ Senior Professor \\ University of Sri Jayewardenepura, Sri Lanka \\ N.N.J.Nawaratne \\ Senior Lecturer \\ University of Colombo, Sri Lanka
}

\begin{abstract}
Though there is a growing interest among academicians and practitioners in respect of green aspects of Human Resource Management (HRM) there is a gap in the theoretical as well as empirical knowledge about environmental related job performance of an employee in an organization. A systematic review of literature reveals that less attention has been paid in valuing, developing, measuring and making use of employee green performance of job by the organizations even though this phenomenon exists in practice. The objectives of this paper are: to introduce a key concept called 'employee green performance of job, to define it nominally, and to identify key dimensions of the concept for the purpose of measuring it in reality based on systematic review of literature. Our attempt resulted in identifying three key dimensions and eleven elements which will be useful for developing an instrument to measure the concept.
\end{abstract}

Key Words: Green Performance of Job, Green Human Resource Management, Employee, Corporate Environmental Management

\section{Introduction}

Nowadays, environmental issues (climate change, global warming, environmental pollution, energy crisis etc.) are getting more concern all over the world. This situation demands the contributions of all individuals as well as organizations to face these issues and challenges in a sustainable manner. In order to respond these issues and challenges in a systematic manner, organizations take certain initiatives such as Environmental Management System (EMS), Cleaner Product (CP), designing and implementing environmental strategies and programs. The ultimate aim of all these initiatives is to reduce the negative environmental impact of the organizations. On the other hand it improves the positive environmental impact or performance of organizations. Environmental performance of an organization or sustainable environmental performance of an organization is a key indicator which reflects the overall outcomes of Corporate Environmental Management (CEM) and its initiatives. In an organizational context, these phenomena require major changes in employees' behaviour (actions and activities), their jobs levels and measuring performance of jobs. It is obvious that current measures and criteria of employee job performance are inadequate to cater the emerging and changing requirements of 
CEM and environmental pressures to the organizations. Hence, we argue that there is a good reason to generate a new concept called 'employee green performance of job' in the context of Green HRM and CEM.

Traditionally, job performance has been broadly studied and has become an established field of research especially in the area of human resource management, production management as well as industrial and organizational psychology (Mardhatillah and Rahman, 2011). Job performance is very important for organizations because it is considered as central to individual, teams as well as organizational effectiveness. Job performance is also a critical factor for both sustainability of the organizations and the well being of the employees (Ilgen and Pulakos, 1999). In considering the importance of job performance for an organization, improving employee's job performance is a must for every organization. Similarly, employee green performance of job is also an important and emerging phenomenon in the context of CEM and Green HRM.

Many scholars (Garavan et al., 2010; Boiral and Paille, 2012; Daily et al., 2009; Ramus and Killmer, 2007; Ramus, 2002) have discussed about the individual and employee level contributions in CEM. They stressed the importance of employee initiatives for improving the environmental practices and performance of the organizations. Strong environmental performance of an organization tends to help that organization to attract, motivate and retain skilled employees (Fernandez et al., 2003) as well. In the CEM context, employees of the organizations view social and environmental issues as part of their daily routines. Employees extend their job function boundaries to include social and environmental activities to manage the environmental impacts of the organization successfully (Valente, 2012).

In recent years, number of scholars have contributed to the understanding of green human resource management (Renwick et al., 2013; Jabbour, 2011; Jackson et al., 2011; Opatha, 2013, Opatha and Arulrajah, 2014 and 2016; Arulrajah, Opatha and Nawaratne, 2015). Today, a number of experts demand the organizations to incorporate environmental management aspects into the employee job analysis and description because that much necessity has raised to response from the individual job levels of the organizations to reduce the negative environmental impacts of the organizations (Zoogah, 2011; Rangarajan and Rahm, 2011; Jabbour, 2011; Jabbour et al., 2010a; Wehrmeyer, 1996).

Environmental management scholars (Renwick et al., 2013; Jackson et al., 2011; Wagner, 2011; Zoogah, 2011; Rangarajan and Rahm, 2011; Jabbour, 2011; Jabbour et al., 2010; Strandberg, 2009; Daily and Huang, 2001; Wehrmeyer, 1996) have linked corporate environmental management requirements into the employee recruitment and selection criteria of HRM in the organizations. Researchers in this area argued that corporate environmental management initiatives and activities of the organizations (e.g. EMS) can only be effectively implemented if the organizations have the right people with the right skills and competencies. Several writers (Kaur, 2011; Renwick et al., 2013; Jackson et al., 2011; Zoogah, 2011; Rangarajan and Rahm, 2011; Jabbour, 2011; Jabbour et al., 2010a; Sharma et al., 2009; Strandberg, 2009; Wehrmeyer, 1996) accentuated the importance of integrating environmental management aspects into the employee performance evaluation system of the organizations. 
Different authors at different points of time have emphasized the critical importance of employee training for the proper implementation of EMS in the organizations and the role that environmental training can play in facilitating the process of environmental management activities of the organization (Renwick et al., 2013; Daily et al., 2012; Jackson et al., 2011; Wagner, 2011; Zoogah, 2011; Massoud et al., 2011; Rangarajan and Rahm, 2011; Jabbour, 2011; Jabbour et al., 2010a; Jabbour et al., 2010b; Strandberg, 2009; Sharma et al., 2009; Jabbour and Santos, 2008a; Jabbour and Santos, 2008b; Renwick et al., 2008; Perron et al., 2006; Zutshi and Sohal, 2004; Daily and Huang, 2001; Madsen and Ulhùi, 2001; Wehrmeyer, 1996).

Scholars in CEM and Green HRM (Kaur, 2011; Renwick et al., 2013; Jackson et al., 2011; Zoogah, 2011; Rangarajan and Rahm, 2011, Jabbour, 2011; Jabbour et al., 2010a; Strandberg, 2009; Daily and Huang, 2001; Wehrmeyer, 1996) stressed the importance of integrating environmental management aspects into the employee reward and incentive management system of the organizations.

According to the Orlitzky et al., (2011) one area of weakness in the literature is the lack of research connecting individuals to corporate sustainability. They also pointed out that research that is focused on the nexus of corporate sustainability and individual employees is beginning to emerge. Though there is an increasing recognition of individual employee contribution to the corporate environmental performance and accentuation of the importance of incorporating corporate environmental management aspects into the job analysis and description, employee recruitment and selection, employee training and development, employee performance evaluation and employee reward and incentive management system of the organizations, a gap exists in measuring employee environmental related job performance separately or within job performance evaluation system being followed by the organizations. We have termed the environmental related job performance by an employee as 'employee green performance of job'. The relationship between the employee green performance of job and organization's environmental performance is shown in Figure 1.

In developing a better alignment between the both concepts reliable and valid measurements for the both are needed. The valid, reliable and generally accepted measurement criteria already exist for measuring organization's environmental performance but not for employee green performance of job. The measurement for employee green performance of job remains an open question. A construct that can be used to measure employee green performance of job needs to be developed in order to provide an alignment between individual employee green performance of job and organization's environmental performance.

Figure 1: Link between Employee Green Performance of Job and Organization's Environmental Performance

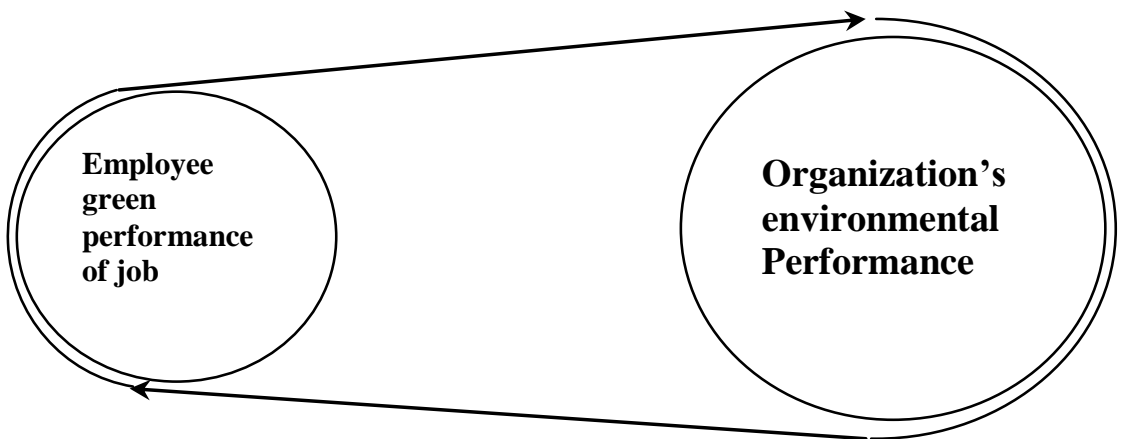


At the same time, no or little research has focused on employee green performance of jobs at the individual level within organizations. We believe that this is a serious omission due to the fact that environmental performance at the organizational level cannot occur without contributions by individuals. In this context, we argue that the relationship between the individual employees' green performance and their perception of the organization's environmental performance will lead to an individual employees' assessment of the alignment between the two and that the rationalization of this assessment underpins their behaviour towards green performance of jobs.

The concept of 'employee green performance of job' in CEM and Green HRM remains largely unexplored. Hence, the objectives of this review are to introduce a key concept called 'employee green performance of job, to define it nominally, and to identify key dimensions of the concept for the purpose of measuring it in reality based on systematic review of literature. Measuring the concept becomes essential when conducting empirical studies in future.

The extensive literature based introduction of this paper has outlined the objective of this review. The rest of our review is organized into five major sections: the first section describes the methodology for this review. The second section presents green aspects of jobs in the context of CEM and Green HRM. The third section explores the operational meaning of job performance and employee green performance of job. The fourth section provides the reasons for measuring employee green performance of job. The final section identifies and summarizes the dimensions of employee green performance of job and provides conclusions with a direction for future empirical studies on the same topic.

\section{Methodology}

As this paper introduces the concept called employee green performance of job and proposes key dimensions towards developing an instrument to measure the construct, this paper uses Tranfield et al., (2003) for reviewing literature with an archival method, which enables the reviewers to structure research and build a reliable knowledge base in this field. The analysis of the review process includes classifying the literature to derive the concept of employee green performance of job and its key dimensions for measuring by using collected publications from the relevant books, journal articles, edited works, and other research papers. This review considers the works on green aspects of jobs and Green HRM appeared directly or indirectly in the literature.

\section{Green Aspects of Jobs}

In the Green HRM context, jobs can be grouped into two categories. They are green jobs and other jobs. Green jobs are the jobs which are directly related to the environmental issues of the company (e.g. environmental manager). Other jobs are having higher potential to contribute to the environmental performance of the organization however, they are not directly related to the environmental management function of the organizations. Really all jobs are not purely related to the environmental issues of the company or green jobs, but contributions of all jobs are required for ensuring the environmental performance of the organization. Green jobs reduce the negative environmental impact of enterprises and economic sectors, ultimately to levels that are sustainable (International Labour Organization-ILO, 2008).

In 2008, United Nations Environment Programme (UNEP) defines green jobs as: 
"positions in agriculture, manufacturing, $R \& D$, administrative, and service activities aimed at alleviating the myriad environmental threats faced by humanity. Specifically, but not exclusively, this includes jobs that help to protect and restore ecosystems and biodiversity, reduce energy consumption, decarbonize the economy, and minimize or altogether avoid the generation of all forms of waste and pollution. A successful strategy to green the economy involves environmental and social full-cost pricing of energy and materials inputs, in order to discourage unsustainable patterns of production and consumption. A green economy is an economy that values both nature and people and creates decent and adequately paid jobs (p.7)”.

According to Collins et al., (2010), growing awareness around energy use and reducing carbon footprints necessitate that things have to be done differently and that there are not only challenges, but also opportunities for more green products and more green jobs. According to this definition for green jobs, almost it covers the most of jobs in an organization. At the same time, this definition indicates that all jobs in an organization have potential to save as green jobs to a certain extent. European Centre for the Development of Vocational Training (2010) stresses:

"Every job can potentially become greener. Understanding the environmental impact of a job, and its possible contribution to greener economies, needs to be mainstreamed into education and training systems (p.2)”.

Thomas et al., (2010) stated that green jobs must include all fields of employment; professional and vocational. Therefore, we can conclude that each job in an organization has potential to generate green performance. That potential green performance can be called as 'employee green performance of job'.

At present and even forever, in performing any job, the job holder is required to think about its negative impact on environment and how to reduce it and also its positive impact on the environment and how to improve it. This phenomenon and concept of green job jointly lead us to develop a concept of 'employee green performance of job'. However, many jobs which are green in principle are not green in practice because of the environmental damage caused by inappropriate practices. The notion of a green job is thus not absolute, but there are 'shades' of green and the notion will evolve over time (ILO, 2008).

\section{Job Performance and Employee Green Performance of Job Job Performance}

According to Hersey and Blanchard (1993), job performance measures the level of achievement of business and social objectives and responsibilities from the perspective of the judging party. Job performance means all the behaviour at work that can make some contribution to organizational goals (Babin and Boles, 1996).

In measuring employee job performance, quantity (how much-compared to other people who do the same or similar kind of work that you do, how much work would you say you do?) and quality (how well- compared to other people who do the same or similar kind of work that you do, how well would you do your job?) of an employee's job are the major dimensions based on the respondents self-report of his/her performance compared to others who do similar work 
(Cheng and Kalleberg, 1996). Accordingly, quantity of work and quality of work are two major dimensions of job performance. In the literature (Yousef, 2000), employees' individual job performance was studied through dimension such as 'quality of performance' and 'productivity or quantity of performance'. Karatepe et al., (2006) showed that trait, competitiveness, selfefficacy and effort are significant predictors of frontline employee job performance.

Sohi (1996) defined performance as behavior evaluated in terms of its contributions to the goals and objectives of the organization. According to Sohi, job performance can be divided into efficiency, production and effectiveness. Efficiency is usually used to evaluate the outcome of an employee's work behaviors, production is generally used to determine the cost of efficiency, and effectiveness stands for the value of efficiency and production. During the past, researchers have made progress in clarifying and extending the performance concept because individual performance is a core concept within work and organizational psychology (Campbell, 1990).

An organization's performance directly depends on the individuals it employs (Arulrajah and Opatha, 2012). The construct of employee job performance has two dimensions. First one refers to 'task performance' (or technical job performance) that is the behaviour associated with maintaining and servicing an organization's technical core and second dimension is about 'contextual performance' (or interpersonal job performance) that is a function of one's interpersonal skill and knowledge that supports the broader social environment in which the technical core must function (Motowidlo and Van Scotter, 1994).

McCarthy and Goffin (2001), used five aspects to assess task performance of employees rated by supervisors of employees. They are: (1) effectiveness in displaying job knowledge and skill, (2) effectiveness in verbal and written communication, (3) effectiveness in taking charge when required, (4) degree to which they set high standards and strive to meet them, and (5) quickness in learning.

In measuring job performance of executive and non-executive employees, a three dimensional measure (traits, behaviours and results) was used by Opatha (2002) in Sri Lankan context which consists of 13 aspects. They are job knowledge, cooperation, dependability, interpersonal relations and communication skills under the dimension of traits; planning work, organizing work, punctuality, attendance and speed covering the dimension of behaviours; and efficiency achievements, completion of work on schedule and quality of work under the dimension of results. An employee's job performance is the extent to which duties and responsibilities have been carried out. It has two major criteria such as quantity of work and quality of work (Opatha, 2015).

According to the above reviewed literature evidences about job performance, it is specifically notable that job performance has two main dimensions. They are: (1) quantity of job performance and (2) quality of job performance. These two dimensions have several subdimensions or elements based on the characteristics of jobs, work setting and nature of the organizations. Based on above understating of job performance, now an attempt is made to define employee green performance of job nominally. In other words, we attempt to give a particular identity or status to the concept of employee green performance of job that we proposed. 


\section{Employee Green Performance of Job}

Employee green performance of job is defined as the extent to which a particular employee has engaged in behaviours (actions and activities) and produced results in respect of greening during a particular period of time. This is really about the environmental related job performance by an employee in an organization within a specific period of time. Every employee is responsible for environmental performance of an organization. Each employee can reduce negative environmental impact of his or her job and also can improve positive environmental impact of his or her job. Hence, the quantitative and qualitative contributions of an employee to reduce the negative environmental effects of the organization as well as to improve the positive environmental effects of the organization within a given period of time can be considered as employee green performance of job. This interpretation reflects an adequate meaning of employee green performance of job in an organizational context. In fact, the two authors of this paper namely Opatha and Arulrajah briefly introduced the concept of employee green performance in 2014. However, it was not an exclusive, comprehensive, and distinct introduction (Please refer to Opatha and Arulrajah, 2014).

Understanding the meaning and dimensions of job performance, and defining the meaning of employee green performance of job are insufficient to identify and propose the dimensions of employee green performance of jobs. In addition to this, further literature exploration is needed in respect of two more aspects. First, we have to explore why organizations have to measure (the need for measuring) employee green performance of job as well as whose green performance should be measured and second, we have to discover that what green or environmental performance components of jobs must be captured by the organizations in measuring employee green performance of job. Hence, we extent our systematic review process towards the first aspect in the next section of this paper and second aspect after that.

\section{The Need for Measuring Employee Green Performance of Job}

In general, there is a necessity to explore the green performance of jobs in the context of Green HRM and CEM because, individual level green performance of each job is critical in reducing overall negative environmental impact of the organization. Green performance of individuals in the workplace is a key input in reducing overall negative environmental impact of the organization and improving overall positive environmental impact of the organization. Green performance of each job is a base for collective and team green performance of the organization.

The environmental HRM functional model of Wehrmeyer (1996) indicates that staff appraisals should take account of environmental issues as well as environmental critical incidents, accepted environmental responsibilities and the success of communicating environmental concerns and policy of the organizations. In implementing environmental or Green HRM in the organizations Revill (2000) also explained the necessity of adoption of environmental performance appraisals in the organizations. Environmental initiatives or improvements should be a part of employees' performance appraisal, as it could be a major motivating factor for employees (Denton, 1999).

The environmental performance of an organization is the responsibility of all employees of that organization (Berry and Rondinelli, 1998). They indicate this as one of the basic principles required for corporate environmental performance and it should be promulgated at all levels of 
the organization. According to Daily et al., (2007), to guide managers in maximizing employee efforts to successfully implement, improve and sustain CEM initiatives (e.g. EMS) of the organizations, measuring employee green performance of job is required. In a survey conducted by Buck Consultants (a global HR consulting firm) in 2009, it was found that 'companies that had appointed individuals to lead organizational green efforts have a much higher prevalence of employees actively involved in their green practices than companies that had not. Findings also demonstrate that corporate operations and HR departments are most often responsible for green programs' (The Greening of HR Survey Results, 2009).

Environmental management scholars and experts (Denton, 1999; Daily and Huang, 2001; Chinander, 2001; Daily et al., 2002; Rothenberg, 2003; Govindarajulu and Daily, 2004) expressed that many organizations are experiencing significant human resource challenges in implementing environmental initiatives. Thus, we argue that it may be due to not measuring green performance of jobs at individual level. In this context, Daily et al., (2009) are also supportive to our argument because they stated that "employees may be unclear as to their role in environmental improvements and unsure of the rewards associated with them (p.244)". Chinander (2001) also confirmed our attribution. Chinander (2001) found that although management adopted extensive steps to measure air, water, and solid waste emissions, they did not evaluate employees based on environmental performance. Further more, according to Denton's survey (1999), regarding environmentally concerned industries in worldwide, it was found that reward practices of organizations (e.g. bonuses, incentives or salaries) were rarely linked to environmental performance of organizations. Thus, although organizations may do expanding environmental initiatives and efforts, rewards for these initiatives and efforts appeared to be lacking. These evidences further validate our argument that there is a strong need for calculating and measuring the employee green performance of jobs in the context of Green HRM.

Organizations need to decide if environmental initiatives or improvements should be a part of employees' performance appraisal, as it could be a major motivating factor for employees (Denton, 1999). Organizations rarely provide incentives, bonuses or salaries that are directly tied to how far and how well environmental goals are met. If their employees' job performance appraisals rarely include an environmental category most of their employees do not become motivated to make or to participate in green decisions (Denton, 1999).

Neto and Jabbour (2010) indicate that one of the greatest challenges in the consolidation of CEM programmes (e.g. Cleaner Production program) is to ensure the engagement of employees in this process. Hence, we assert that if organizations develop appropriate systems to measure the employee green performance of job, then this greatest challenge can be transformed as a greatest opportunity in successfully managing organizational environmental performance.

According to Lucas (2010), performance evaluation schemes of employees should comprise an environmental component. Environmental strategy is linked more powerfully to environmental performance through the development of performance measures. The environmental performance of organizations, business units, facilities, teams, managers, and all other employees must be measured and must be part of the way they are evaluated for success (Epstein and Roy, 
2000). The importance of the involvement of all employees of an organization in CEM initiatives and activities has been considered as a key factor in the literature (Handfield et al., 2001).

The success of CEM initiatives of organizations heavily depends on the active involvement of the organization's individual employees at all levels (Hart, 1995; Russo and Fouts, 1997; Sharma and Vredenburg, 1998; Klassen and Whybark, 1999; Buysse and Verbeke, 2003). According to McCloskey and Maddock (1994), the organization and its whole workforce are encouraged to work towards an environmental ethic, and environmental responsibility is part of every employee's function. Staff performance and review will include evaluation of, and reward for, the employee's contribution to successful environmental and commercial performance of the company.

The reviewed literature has revealed two key findings at this point: First, there are strong justifications and evidences for why organizations have to measure (the need for measuring) employee green performance of job (e.g.Wehrmeyer, 1996; Denton, 1999; Revill, 2000; Daily and Huang, 2001; Chinander, 2001; Daily et al., 2002; Rothenberg, 2003; Govindarajulu and Daily, 2004; Daily et al., 2007; Daily et al., 2009). Hence, recognizing the concept of 'employee green performance of job' at individual level, and developing a systematic and organized approach to measuring it will improve the environmental performance of the organizations. Second, the reviewed literature also revealed that every employee and job should involve in $\mathrm{CEM}$ /green works and initiatives to help the organization to succeed in organizational environmental performance (McCloskey and Maddock, 1994; May and Flannery, 1995; Berry and Rondinelli, 1998; Denton, 1999; Epstein and Roy, 2000; Handfield et al., 2001). Therefore, the measuring of employee green performance of job includes all employees of an organization irrespective to their categories and types of jobs, and levels of management. As we stated earlier, the next section of our review focuses on what green or environmental performance components of a job to be captured by the organizations in measuring employee green performance of job. This is about the dimensions of employee green performance of a job.

\section{Dimensions of Employee Green Performance of Job}

In searching to explore the scope and depth of employee green performance of jobs, we have identified three categories or dimensions of employee green performance of jobs. They are: (1) efficient use of input resources effectively by employees when they perform their day to day job tasks, duties and responsibilities, (2) innovative environmental initiatives of employees, and (3) employee contribution to the environmental management initiatives of the organization.

\section{(1) Efficient Use of Input Resources Effectively}

An efficient use of input resources effectively can be considered as one of the key dimensions of employee green performance of job for an organization. This dimension consists of mainly three key performance elements: reducing existing levels of input resources usage, sharing environmentally friendly actions and behaviour, and protection of corporate environmental image.

\section{(a) Reducing the Existing Levels of Input Resources Usage}

Employees contribute to improve environmental performance of company by reducing their existing level of input resource usage in the workplace in the form of waste and pollution. 
Truly effective environmental protection requires the prevention of pollution rather than the control of wastes at the end of the pipeline. Pollution prevention is the use of materials, processes or practices that minimize or eliminate the creation of pollutants or wastes at the source (Berry and Rondinelli, 1998). These aspects are impossible without the efforts of employee in an organization.

Several authors have produced evidence that more effective environmental management can allow organizations to make better use of resources (Graedel and Allenby, 2001; King and Lenox, 2001). According to Berry and Rondinelli (1998), pollution prevention is a powerful business strategy because it encourages the efficient use of raw materials and reduces the costs of waste. How employees are practicing in their day to day job should be monitored and measured. They also empathized that performance indicators must be developed for each area to focus management and employees on ways of reducing adverse environmental impacts of energy generation and distribution. Employees are the source of innovation and creativity of an organization. They have potential attitudes, ability and motivation to reduce waste, input resources and pollution while simultaneously improving overall performance.

There are employees who act beyond job description, formal policies and reward systems of the organization in progressing sustainability initiatives of the companies (Daily et al., 2009). These employees' green performance of jobs should be considered by the organization because they are contributing to the environmental performance of organizations in terms of efficient use of input resources effectively.

According to Rothenberg (2003), there are a number of resources that employees can contribute to environmental improvements and performance of the organization, such as time and attention etc. How employees are using organizational resources (all inputs) efficiently and effectively will determine the green performance of their jobs as well as organization's environmental performance.

According to Garavan et al., (2010), employees who have a high level of environmental awareness and environmental concern may feel a stronger moral obligation to perform environmentally friendly actions and initiatives voluntarily in the organizations. At the same time the moral obligation of employee towards environment is necessary to utilize the natural environmental resources which are used by an organization in an efficient and effective manner.

A study conducted by Melnyk et al., (2003) in order to assess the impact of EMS on corporate and environmental performance found that the impact of environmental activities on corporate performance is strongly affected by the presence of a formally certified environmental management system. The reason is the resource based view of the organization (Wernerfeldt, 1984; Russo and Fouts, 1997) supporting the idea that the CEM initiatives (e.g. environmental management system) provide the organization with detailed information for critical functions and resource usages. These systems and functions are necessary for the organization and its workforce to reduce pollution, wastage, materials, other input resources and energy usage etc. and ultimately these lead to improve overall performance. 
Kitazawa and Sarkis (2000) emphasize the significance of employee efforts in managing continuous source reduction programs in three industrial ISO 14000 certificated companies. In accordance with Denton (1999), the economic savings made by Dow Chemical's energy conservation and Waste Reduction Always Pays Programs (WRAP) have in large part taken place because of employee activities and involvement.

\section{(b) Sharing Environmentally Friendly Actions and Behaviours}

In some organizations, individual employees may show some sort of environmentally friendly behavioural patterns such as sharing knowledge to save energy or prevent pollution in the workplace, suggesting solutions aimed at reducing waste, representing the organization at environmental conferences/workshops and collaborating with the environmental department/teams to implement green initiatives. In practice, these behaviours may appear minor and ordinary. However, promoting these types of employee behviours can have a significant impact and contributes to improving environmental performance of the organizations (Ramus, 2001; Ramus and Killmer, 2007; Boiral, 2005).

Environmental management system provides a tool for employees and managers to take environmental impacts into consideration when performing daily job functions (Ramus and Steger, 2000; Ramus, 2002). Boiral (2009) argued that complex environmental issues of the organizations cannot be handled through formal systems of the organization alone. Those issues require employee voluntary involvement in sharing tacit knowledge and helping to implement the solutions.

Daily et al., (2009) also believed that individuals/employees with a deep sense of environmental concern will likely insert their environmentally friendly actions in the workplace. They also argued that individuals who engage in environmentally friendly behaviours out of a moral sense of obligation may perform similar behaviours and actions as employees in the workplace.

Employees who reduce waste, energy and other natural resource consumptions through their self-understanding and/or learn from his/her managers, supervisors and/or the environment in which they live can be considered as a key aspect of employee green performance of job. According to Ramus (2002), employees need supervisory support (daily behaviors aimed at encouraging environmental actions) in order to focus their creative energy on organization environmental problem solving.

According to Mischel (1973) and Shamir et al., (1993), employees frequently find themselves in situations where they have to perform some extra-role behaviour in order to reduce bad impact to environment but they are not formally required for an employee's job. This aspect was reiterated by the Ramus and Killmer (2007) "employees often find themselves in situations without clear goals or certainty about the organizational rewards associated with the optional behaviour of promoting environmentally beneficial changes (p.555)". This optional extra-role behaviour of the employee which is contributing to the CEM must be considered when measuring employee green performance of jobs. In accordance with Boiral and Paille (2012, p.433), Ramus and Killmer's model (2007) also 
suggests that "employee eco-initiatives can be predicted and measured from a behavioural perspective. Even though, the nature of these extra-role eco-initiatives and the appropriate measurement method remain unclear". Therefore, the level of sharing environmentally friendly actions and behaviour in the workplace with peers can be considered as an element of this dimension.

\section{(c) Protection of Corporate Environmental Image of the Organization}

An environmentally friendly company will represent a better image and will be able to attract not only more customers but also a more able and dedicated workforce (Dechant and Altman, 1994; Quazi, 2001). Thus, protecting the corporate environmental image can be considered as one of the key responsibilities of the employees. Communicating environmental performance is important to corporate image and stakeholder support. Employees have potential to play an active role in protecting corporate environmental image of the organization (Berry and Rondinelli, 1998). Employees are frequently regarded as ambassadors underpinning their organization's corporate identity and image, and they are often expected to uphold and display their organization's social and ethical values (Morsing, 2006).

Therefore we argue that in assessing employee green performance of job, the level of contribution of employees in protecting corporate environmental image must be considered as an element. The above three elements from the literature form a sub-dimension called as 'efficient use of input resources effectively'. Figure 2 shows diagrammatic representation of these three elements which can be applied in conceptualizing employee green performance of job.

\section{Figure 2: Elements of the Dimension of Efficient Use of Input Resources Effectively}

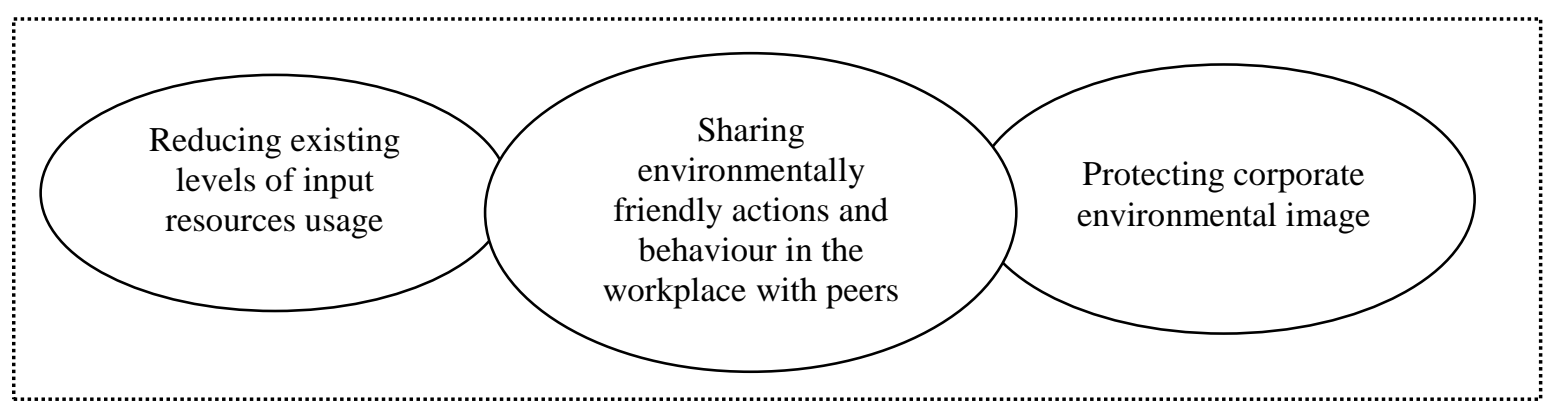

In summary the literature suggests reducing existing levels of input resources usage, sharing environmentally friendly actions and behaviour and protection of corporate environmental image of the organization as key elements of employee green performance of job which build a dimension called 'efficient use of input resources effectively'.

\section{(2) Innovative Environmental Initiatives of Employee}

The employee contribution in the form of creativity and innovation is another key dimension of employee green performance of job. According to the literature, there is a clear evidence for this dimension to include in assessing employee green performance of job. Innovative environmental initiatives (Ramus, 2002) which are really useful to improve the organization environmental 
performance can take the form of developing environmentally friendly systems, processes, practices, products and services. This dimension consists of mainly two key performance elements: creativity in solving environmental problems and level of innovation in environmental initiations. In this context, creativity means the idea-creating sense but innovation means actionproducing sense in relation to solving environmental problems or in environmental initiations.

\section{(a) Employee Creativity in Solving Environmental Problems}

According to Beard and Hartmann (1997), employee creativity is an important environmental problem-solving resource for organizations. Fernández et al., (2003) accentuated that ecoinitiatives should take place from creative ideas jointly developed by all the employees. Moreover, they indicate that systems and approaches need to be developed to involve employees by giving them autonomy to develop creative solutions to solve problems and to make the best use of their competencies.

Ramus and Steger (2000) define eco-initiatives as the creative suggestions from individuals or teams of employees that have the potential to improve an organization's environmental performance and hence contribute to corporate greening. If this phenomenon is not measured or rewarded by considering as employee green performance of job, then it is very difficult to promote and sustain eco-initiatives in the organizations. For example, organizations can use number of new ideas, solutions, practices, and suggestions developed or generated by the employee to reduce negative impact on the environment and to improve positive impact on the environment in a given period of time. Thus, we insist that in assessing employee green performance of job, the level of employee creativity in solving environmental problems must be considered as an element.

\section{(b) Employee Innovation in Environmental Initiations}

Innovation, or the lack of it, is also an issue in the implementation of CEM programs (Tinsley, 2002). Eco-initiatives may lead to pollution reductions, waste reductions, the development of new energy or resource-saving products and services, the greening of supply or distribution networks, and the design of products for reuse and recycle etc. (Ramus and Steger, 2000). These initiatives have considerable inputs for organization's business performance, as well as in determining the success of organization's environmental management activities and objectives (Kolluru, 1994; Ruiz-Quintanilla et al., 1996). Research revealed that eco-initiatives of employees can substantially affect business performance, as well as determining the success of organizations' efforts to implement environmental management objectives (Kolluru, 1994; Ruiz-Quintanilla et al., 1996). Employees of an organization should be able to make changes to improve the environment without much more management interference (Govindarajulu and Daily, 2004). Thus, in order to encourage environmental management related innovations among the employees we should include it as a criterion in measuring employee green performance of job.

Implementation of CEM initiatives requires a high level of technical and management skills among employees due to the facts that the company will develop innovation-focused environmental initiatives and programmes that have a significant impact on the sustainable competitive advantage of the organizations (Callenbach et al., 1993). For example, in the Xerox Corporation, which has reward and recognition programmes, employees achieved high 
levels of innovation in waste reduction, reuse and recycling (Fernández et al., 2003). Another key example was Walmart's continuous recognition of associates and their stories of innovative achievement. In 2011, they recognized an associate who brought to management attention the value of taking the lights out of break room vending machines. This action saves \$1 million per year to the company (www.triplepundit.com, 2012). Employee environmental innovations exist in many organizations today (Ramus, 2002). These are the eco-initiatives originated by individual employees and teams that improve the environmental performance of the organizations. Ramus (2002) also stressed that environmental management initiatives must occur at all levels within organizations, resulting in creative ideas from managers, office personnel, blue-collar workers, or other types of employees. For example, organizations can use number of new ideas, solutions, practices, and suggestions implemented successfully and the amount of money or resource saved due to that implemented innovation in a given period of time.

The above literature evidences indicate that there is a necessity to incorporate innovative environmental initiatives of employee as a dimension in measuring employee green performance of job in an organization which will sustain the contribution of individual to the overall environmental performance of the organization. The above elements from the literature form a sub-dimension called as 'innovative environmental initiatives of employee' (Figure 3) which can be applied in conceptualizing employee green performance of job.

\section{Figure 3: Elements of the Dimension of Innovative Environmental Initiatives of Employee}

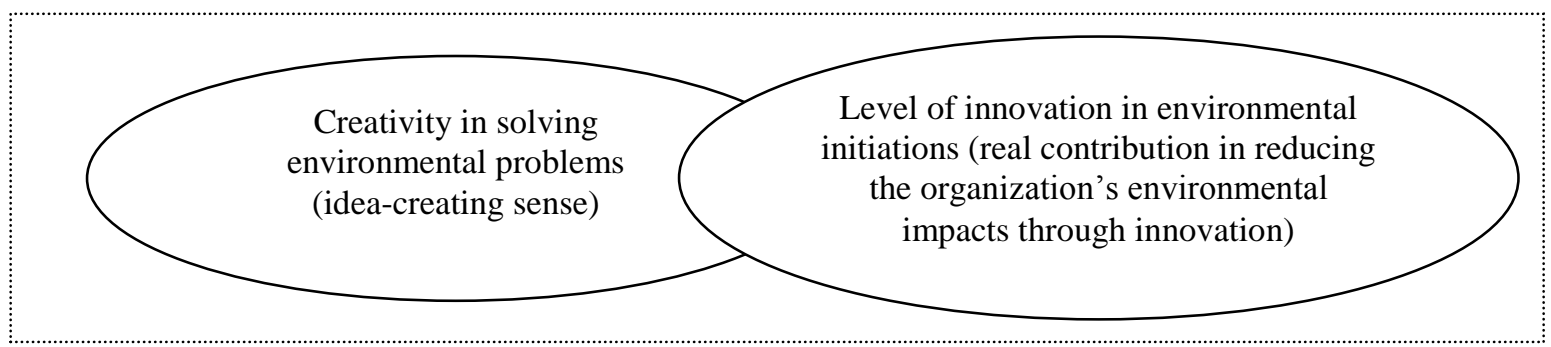

In summary, the literature suggests that the level of employee creativity in solving environmental problems, and the level of employee innovation in environmental initiations are the two key elements of the dimension of innovative environmental initiatives of employee which is the second key dimension of employee green performance of job.

\section{(3) Employee Contribution to the CEM Initiatives}

The employee contribution to the CEM initiative is the third key dimension of employee green performance of job in an organization. This dimension includes six key performance elements. The elements of this dimension are: the level of employee achievement of specific environmental performance targets/goals (quantity), the level of quality in achieving environmental performance objective, goals and targets by the employees, the level of supportive job behaviour of employee towards in achieving specific environmental performance targets, the level of 
employee contribution to implement CEM initiatives, the level of employee contribution to improve CEM initiatives, and the level of employee contribution to sustain CEM initiatives.

\section{(a) The Level of Employee Achievement of Specific Environmental Performance Targets/Goals (Quantity)}

Environmental Management Systems provide a tool for employees and managers to take environmental impacts into consideration when performing daily job functions (Ramus 2002). This situation leads to generate green performance from each job. Thus, in an organization which is practicing environmental management there is a possibility or existence of green performance of job.

Many organizations now consider the CEM initiatives of the organizations as a viable way to create a sustainable competitive advantage (Franklin, 2008; Sharma and Vredenburg, 1998). There is no explicit written policy indicating that employees are responsible for environmental performance but it is clear to employees that company expects contribution and commitment from them in achieving environmental goals of the organization (Ramus, 2002).

Some organizations in USA (e.g. Browning-Ferris Industries, Coors Brewing and Huntsman Chemical) have linked employees and managers' performance-related bonuses to their meeting environmental targets (e.g. reducing amount of waste etc.). A manager/employee does not get any bonus when his/her individual environmental goals are not met (Wehrmeyer, 1997). In some organizations (e.g. Coors Brewing in USA) employees receive increases in the organization's profit-sharing plan when their environmental initiatives, activities and efforts cut overall costs (Wehrmeyer, 1997).

Another example in the US context, the director of environment, health and safety of Huntsman Chemical, receives one half of the incentive pay from the company's profits and the other half is linked to specific environmental goals (Wehrmeyer, 1997). According to Rothenberg (2003), organizations are expecting employee participation and contribution as a means to achieve environmental goals.

Another example is that managers can request employees to bring precise green ideas which are related to their individual jobs to their performance evaluation discussions. These ideas can be brainstormed together to include them into the objectives/targets for the forthcoming year performance evaluation while considering organization's environmental policies. Attaining these objectives/targets can be considered as their environmental performance (Mandip, 2012).

Many organizations (e.g. Xerox and Wal-Mart) have recognized environmental policies, objectives, goals and targets for their employees, whose environmental position is assessed as one of the criteria of organizational evaluation programmes of individual performance (Neto and Jabbour, 2010). Wee and Quazi (2005) stress the importance of the involvement of employees in defining specific environmental objectives of the organization and through which to achieve a cooperative environmental policy and vision of the organization. As a result of these evidences we stress that the level of employee achievement of specific 
environmental performance targets/goals must be considered as one of the elements of the dimension of employee contribution to the CEM initiatives.

\section{(b) The Level of Quality in Achieving Environmental Performance Objective, Goals and Targets by the Employees}

In measuring employee green performance of job, quality of job performance is a key phenomenon. Even though there is lack of direct literature to underpin this facet from the CEM context but three are adequate evidences from the general job performance literature (e.g. Cheng and Kalleberg, 1996; Yousef, 2000). In achieving environmental performance objective, goals and targets by the employees, organization must check whether those achievements are taking place without violating relevant organization's environmental policy, rules, regulations, ethics and procedures or not. For example, in a manufacturing organization, employees may dump the waste without knowing management and may try to show zero waste in a particular manufacturing facility. Hence, quality in achieving environmental performance objective, goals and targets by the employees must be considered as a key element in measuring employee green performance of job.

\section{(c) The Level of Supportive Job Behaviour of Employee Towards in Achieving Specific Environmental Performance Targets}

According to Epstein (1996), to have environmental targets for improving organization environmental performance is a very important aspect in CEM. Organizations can set the targets after measuring the environmental impacts of the organization. In this context, we suggest that after quantifications of environmental impacts, environmental performance improvement targets must be set systematically by using top down approach. It means, first we must set the environmental performance targets at overall company level, business units level, department level and individual job level as far as possible by using existing base line data and systems. Meanwhile an organization can use the bottom up approaches also in order to align (e.g. environmental initiatives of employee, active member of green team of the organization, employees having personal environmental plan-PEP and etc.) employees initiatives, actions, and behaviours towards achieving environmental performance targets of the organization because this alignment is also very important in inculcating environmental performance culture within the organizations.

Undoubtedly in any organization, it seems obvious that any new management program's (e.g. EMS) success may depend on how employees respond (Govindarajulu and Daily, 2004). Supportive behaviour and positive attitudes of the employees within the organization can act as a determining factor for successful integration, coordination and maintenance of CEM activities and actions of the organizations (Zutshi and Sohal, 2005). The effective delivery of corporate social and environmental responsibility initiatives of an organization is heavily dependent upon employee responsiveness and support (Collier and Esteban, 2007).

According to the Daily et al., (2007, p.99), "while individual contributions to the environmental efforts of an organization are important, working in teams is necessary for the implementation of an effective environmental management system". 
In some organizations environmental management initiatives, activities and actions are largely driven and supported by the employees themselves. This indicates the employee role in the environmental management efforts of the organizations (Dahlmann et al., 2008). As a result, we emphasize that the level of supportive job behaviour of employee towards achieving specific environmental performance targets must be considered as one of elements under the dimension of employee contribution to the CEM initiatives.

Apart from these, organizations have to fulfill the environmental related laws (national as well as global) and standards (e.g. ISO 14001: EMS, ISO 50001: energy management, clearer production, chemical leasing, OHSAS: 18001). These laws and standards require certifications, organizational level initiatives and renewal. Therefore, organizations are required to perform a lot of tasks, duties and responsibilities to implement, improve and sustain those initiatives dynamically which are mainly related to CEM. These CEM initiatives are really some sort of dynamic and cyclical operations, organizations have to respond immediately to show their readiness in reducing negative environmental impact of the organizations. The levels of employee contribution to implement, improve, and sustain CEM initiatives are three key aspects in CEM. Hence, in measuring employee green performance of job actually, organizations must include employees' contributions in terms of implementation, improvement and sustainability of CEM initiatives.

\section{(d) The Level of Employee Contribution to Implement CEM Initiatives}

Employees contribute to implement (put into practice and implant permanently) the CEM initiatives of the organization (e.g. environmental management system, energy management system and cleaner production). Employees can contribute more effectively when management moves the decision power down to the employees, allowing them the freedom and power to make suggestions and implement good environmental practices (Wever and Vorhauer, 1993). Hutchinson (1996) stated that the successful implementation of corporate environmental policies and initiatives depends on environmental responsibility being shared with employees and managers at all levels of the organization. Researchers have suggested that an employee and process focus is essential in integrating management systems and implementing a sustainability program (Pojasek, 2007).

In successfully implementing EMS in the organizations, maximizing employee efforts is one of the key aspects in CEM (Daily et al., 2007). An employee is a key factor that acts as a prerequisite to succeed in any system implementation including CEM initiatives (Yee et al., 2010).

Even though CEM initiatives (e.g. ISO 14001) were created to help organizations, there are some factors that may prevent a company from successfully implementing those initiatives, out of which the irritation from employees who may oppose the increase in their responsibilities of jobs or lack of commitment of workers is a key factor (Poksinska et al., 2003; Chavan, 2005; Psomas et al., 2011). Therefore these kinds of instance necessitate the recognition and measurement of employee green performance of job to get the commitments of employees. Hence, we insist that the level of employee contribution to implement CEM initiatives must be considered as an element of the dimension of employee contribution to the CEM initiatives. 


\section{(e) The Level of Employee Contribution to Improve CEM Initiatives}

Not only the employee contribution during the implementation but also their contribution for the improvement must be considered by the organizations in measuring employee green performance of job.

Implementation of CEM initiatives is not enough to the success of environmental performance of the organization. After the successful implementation, the continuous improvement is also needed. In this context, inclusion of the employee contribution to the improvement of what is implemented, must also be accounted in measuring the real green performance of employees.

Continual improvement is a must for sustainable business and is driven by conformance and performance systems. These systems present an opportunity not commonly seized to propel employee behavior and involvement (Eyceoz, 2009). Therefore, in measuring employee green performance of job this review has considered the level of employee contribution to improve the CEM initiatives. Thus, we insist that the level of employee contribution to improve CEM initiatives must be considered as an element of the dimension of employee contribution to the CEM initiatives.

\section{(f) The Level of Employee Contribution to Sustain CEM Initiatives}

The direct impact of human resource on the implementation and maintenance of environmental business practices and indispensability of employees for the reduction of environmental impacts were also reported by Kitazawa and Sarkis in 2000.

A study conducted by the Jabbour (2011, p.104) in 94 Brazilian organizations with ISO 14001 certification found that "the little formalization of the inclusion of environmental issues in traditional human resource practices, which can later badly affect the good performance observed.." in CEM initiatives of the organizations. This indicates that systematic formalization is very important to sustain the performance achieved by the organizations during implementation of CEM activities and actions.

Creating and sustaining a pro-environment organization requires that organization to hire employees who are willing to engage in environmental management activities of the organization (Renwick et al., 2013). This fact emphasizes the importance of employee contribution in implementing, improving and sustaining environmental management initiatives of the organization. Hence, we insist that the level of employee contribution to sustain CEM initiatives must be considered as an element of the dimension of employee contribution to the CEM initiatives.

These elements derived from the literature form a sub-dimension called 'employee contribution to the CEM initiative' (Figure 4) which can be applied in operationalizing employee green performance of job. 


\section{Figure 4: Elements of the Dimension of Employee Contribution to the CEM Initiatives}

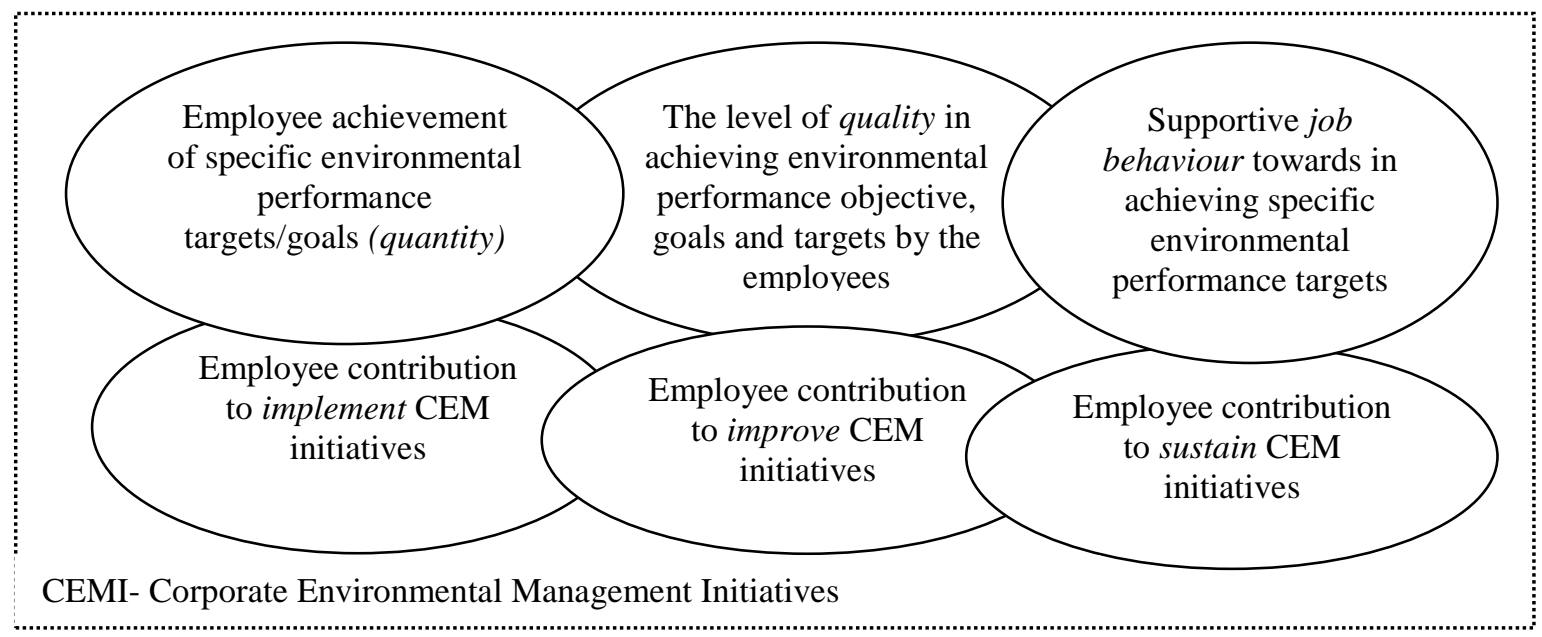

In summary, the literature suggests that level of employee achievement of specific environmental performance targets/goals (quantity), the level of quality in achieving environmental performance objective, goals and targets by the employees, the level of supportive job behaviour of employee towards in achieving specific environmental performance targets, the level of employee contribution to implement CEM initiatives, the level of employee contribution to improve CEM initiatives, and the level of employee contribution to sustain CEM initiatives are the six key elements of the dimension of employee contribution to the CEM initiatives.

\section{Conclusion}

Every employee is responsible for environmental performance of an organization. Each employee can reduce the negative environmental impact and also can improve the positive environmental impact of the organization. We define the environmental related job performance by an employee as 'employee green performance of job'. It is the extent of engagement by a particular employee in taking actions, doing activities, and producing results in respect of greening during a certain period of time. Hence, the contributions of an employee to reduce the negative environmental impact of the organization as well as to improve the positive environmental impact of the organization within a given period of time are considered under the concept. The concept of employee green performance of job is applicable and measurable to all employees in their works or job context in an organization.

Our review attempt revealed that the concept of employee green performance of job has certain key dimensions and elements under each key dimension. Three key dimensions were identified (Figure 5), and they include: (1) efficient use of input resources effectively by employees when they perform their day to day job tasks, duties and responsibilities, (2) innovative environmental initiatives of employees and (3) employee contribution to the CEM initiatives. 
Figure 5: Three Key Dimensions of Employee Green Performance of Job

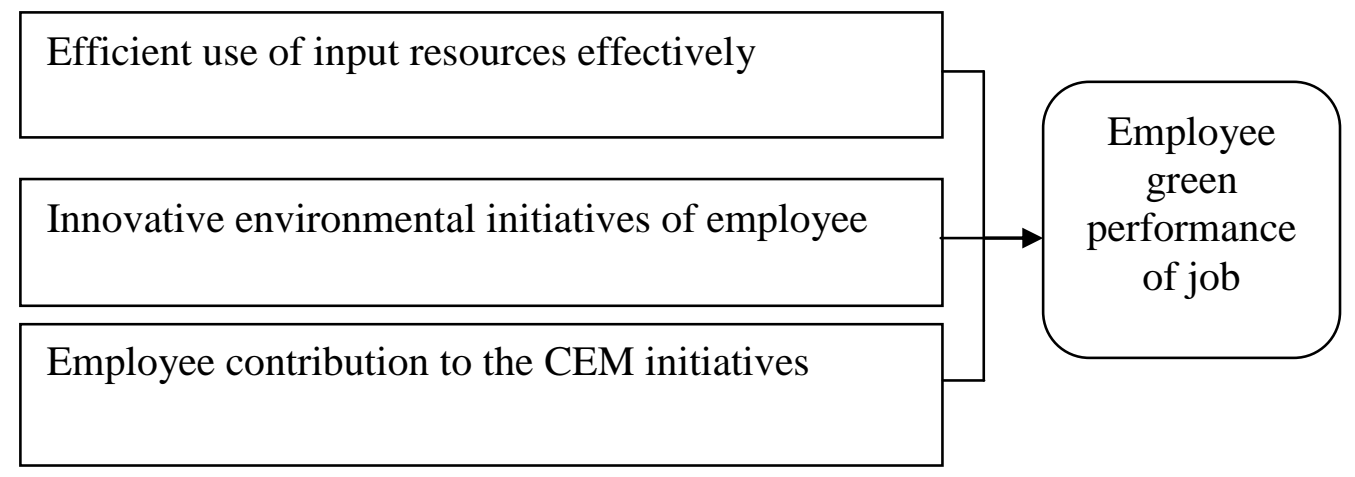

The identified three key dimensions and the eleven elements under the key dimensions could be utilized to develop an instrument to measure the concept of employee green performance of job. Hopefully this paper has a significant value for future empirical studies that involve this concept.

\section{References}

Arulrajah, A. A., Opatha, H. H. D. N. P. and Nawaratne, N. N. J. (2015), Green Human Resource Management Practices: A Review, Sri Lankan Journal of Human Resource Management, Vol. 5, No. 1, pp. 1-16.https://doi.org/10.4038/sljhrm.v5i1.5624.

Arulrajah, A. A. and Opatha, H. H. D. N. P. (2016), Analytical and Theoretical Perspectives on Green Human Resource Management: A Simplified Underpinning, International Business Research, Vol. 9, No. 12, pp. 153-164. http://dx.doi.org/10.5539/ibr.v9n12p153.

Arulrajah, A. A. and Opatha, H. H. D. N. P. (2012), An exploratory study on the personal qualities/characteristics expected by the organizations for key HRM jobs in Sri Lanka. Sri Lanka Journal of Human Resource Management, Vol. 3, No. 1, pp. 32-48.

Babin, J. and Boles, S. (1996), The effect of perceived co-worker involvement and supervisor support on service provider role stress, performance, and job satisfaction, Journal of Retailing, Vol. 72, No. 1, pp. 57-75.

Beard, C.M. and Hartmann, R. (1997), Sustainable Design - Rethinking New Business Products, Journal of Sustainable Product Design, Vol. 3. pp. 18-27.

Berry, M.A. and Rondinelli, D.A. (1998), Proactive corporate environmental management: A new industrial revolution, Academic Management Executive, Vol. 12, No. 2, pp. 38-50.

Boiral, O. (2005), The impact of operator involvement in pollution reduction: Case studies in Canadian chemical companies, Business Strategy and the Environment, Vol. 14, No. 6, pp. 339-360.

Boiral, O. (2009), Greening the corporation through organizational citizenship behaviors, Journal of Business Ethics, Vol. 87, No. 2, pp. 221-236.

Boiral, O. and Paille, P. (2012), Organizational Citizenship Behaviour for the Environment: Measurement and Validation, Journal of Business Ethics, Vol. 109, pp. 431-445, DOI 10.1007/s10551-011-1138-9.

Buysse, K. and Verbeke, A. (2003), Proactive environmental strategies: a stakeholder management perspective, Strategic Management Journal, Vol. 24, No. 5, pp. 453-470. 
Callenbach, E., Capra, F., Goldman, L., Lutz, R. and Marburg, S. (1993), Eco-Management: The Elmwood Guide to Ecological Auditing and Sustainable Business, Berrett-Koehler, San Francisco, CA.

Campbell, J.P. (1990), Modeling the performance prediction problem in industrial and organizational psychology, In Dunnette, M.D. and Hough, L. M. (eds.), Handbook of industrial and organizational psychology, Palo Alto: Consulting Psychologists Press.

Chavan, M. (2005), An appraisal of environment management systems: a competitive advantage for small businesses, Management of Environmental Quality: An International Journal, Vol. 16, No. 5, pp. 444-463.

Cheng, Y. and Kalleberg, A.L. (1996), Employee Job Performance in Britain and the United States, Sociology, Vol. 30, No. 1, pp. 115-129.

Chinander, K. R. (2001), Aligning accountability and awareness for environmental performance in operations, Production and Operations Management, Vol. 10, No. 3, pp. 276-291. DOI: 10.1111/j.1937-5956.2001.tb00375.x.

Collier, J. and Esteban, R. (2007), Corporate social responsibility and employee commitment, Business Ethics: A European Review, Vol. 16, No. 1, pp. 19-33.

Collins, D., Bray, M. and Burgess, J. (2010), Green Jobs, Environmental Sustainability \& Industrial Relations, Indian Journal of Industrial Relations, Vol. 45, No. 4, pp. 522-537.

Dahlmann, F., Brammer, S. and Millington, A. (2008), Environmental management in the United Kingdom: new survey evidence, Management Decision, Vol. 46, No. 2, pp. 264-283.

Daily, B.F. and Huang, S. (2001), Achieving Sustainability Through Attention to Human Resource Factors in Environmental Management, International Journal of Operation and Production Management, Vol. 21, No. 12, pp. 1539-1552.

Daily, B.F., Bishop, J. W. and Govindarajulu, N. (2009), Conceptual model for organizational citizenship behavior directed toward the environment, Business \& Society, Vol.48, pp. 243256. DOI: $10.1177 / 0007650308315439$.

Daily, B.F., Bishop, J.W. and. Massoud, J.A. (2012), The role of training and empowerment in environmental performance: A study of the Mexican maquiladora industry, International Journal of Operations \& Production Management, Vol. 32, No. 5, pp. 631-647.

Daily, B. F., Bishop, J.W. and Steiner, R. (2002), The impact of human resource management practices on employee perceptions of environmental performance, Proceedings at the National Decision Science Institute, San Diego, CA.

Daily. B.F., Bishop. J.W. and Steiner, R. (2007), The Mediating Role of EMS Teamwork as it Pertains to HR Factors and Perceived Environmental Performance, Journal of Applied Business Research, Vol. 23, No. 1, pp. 95-110.

Dechant, K. and Altman, B. (1994), Environmental leadership: from compliance to competitive advantage, Academy of Management Executive, Vol. 8, No. 3, pp. 7-27.

Denton, D.K. (1999), Employee involvement, pollution control and pieces to the puzzles, Environmental Management and Health, Vol. 10, No. 2, pp. 105-111.

Epstein, M. (1996), Measuring corporate environmental performance: Best practices for costing and managing an effective environmental strategy, Chicago: Irwin.

Epstein, M.J. and Roy, M.J. (2000), Managing Corporate Environmental Performance: $a$ multinational perspective, INSEAD, European Institute of Business Administration, Fontainebleau, France, pp. 1-34.

European Centre for the Development of Vocational Training (ECDVT). (2010), Skills for green jobs European Synthesis Report, p.2, ISSN: 1608-7089. 
Eyceoz, Z.O. (2009), Employee Involvement in the Implementation of a Sustainability Strategy, A Thesis in the Field of Sustainability and Environmental Management for the Degree of Masters of Liberal Arts in Extension Studies, Harvard University, pp.1-80.

Fernandez, E., Junquera, B. and Ordiz, M. (2003), Organizational culture and human resources in the environmental issue: A review of the literature, International Journal of Human Resource Management, Vol. 14, pp. 634-656. DOI: 10.1080/0958519032000057628.

Franklin, D. (2008), Just good business: A special report on corporate social responsibility. The Economist, Retrieved from http://www.economist.com/ special reports/display Story.cfm?story_id=10491077.

Garavan,T.N., Heraty, N., Rock, A. and Dalton. E. (2010), Conceptualizing the Behavioral Barriers to CSR and CS in Organizations: A Typology of HRD Interventions, Advances in Developing Human Resources, SAGE Publications, Vol. 12, No. 5, pp. 587-613.

Graedel, T. and Allenby, B. (2001), Industrial Ecology. $2^{\text {nd }}$ ed, Prentice-Hall Publishers: New York, USA.

Govindarajulu, N. and Daily, B.F. (2004), Motivating employees for environmental improvement, Industrial Management \& Data Systems, Vol. 104, No. 4, pp. 364-372.

Handfield, R.B., Melnyk, S.A., Calantone, R.G. and Curkovic, S. (2001), Integrating environmental concerns into the design process: The gap between theory and practice, IEEE Transactions on Engineering Management, Vol. 18, pp. 189-208.

Hart, S.L. (1995), A natural-resource-based view of the firm, Academy of Management Journal, Vol. 20, No. 4, pp. 986-1014.

Hersey, P. and Blanchard, K.H. (1993), Leadership Style: Attitudes and Behaviors, Prentice Hall, Englewood Cliffs, NJ.

Hutchinson, C. (1996), Corporate strategy and the environment, In Welford, R. and Starkey, R. (eds.), Business and the environment, London: Earthscan, pp.85-104.

Ilgen, D.R. and Pulakos, E.D. (1999), The changing nature of performance: Implication for staffing motivation and development, United States: HB Printing.

International Labour Organization-ILO. (2008), Green Jobs: Facts and Figures, Geneva.

Jabbour, C.J.C. (2011), How green are HRM practices, organizational culture, learning and teamwork? A Brazilian study, Industrial and Commercial Training, Vol. 43, No. 2, pp. 98 105.

Jabbour, C.J.C. and Santos, F.C.A. (2008a), The central role of human resource management in the search for sustainable organizations, The International Journal of Human Resource Management, Vol. 19, No. 12, pp. 2133-2154.

Jabbour, C.J.C. and Santos, F.C.A. (2008b), Relationships Between Human Resource Dimensions and Environmental Management in Companies: Proposal of a Model, Journal of Cleaner Production, Vol. 16, No. 1, pp. 51-58.

Jabbour, C.J.C., Santos, F.C.A. and Nagano, M.S. (2010a), Contribution of HRM throughout the stages of environmental management: methodological triangulation applied to companies in Brazil, The International Journal of Human Resource Management, Vol. 21, No. 7, pp. 1049-1089.

Jabbour, C.J.C., Teixeira, A.A., Oliveira, J.H.C. and Soubihia, D.F. (2010b), Managing environmental training in organizations: Theoretical review and proposal of a model, Management of Environmental Quality: An International Journal, Vol. 21, No. 6, pp. 830844. 
Jackson, S.E., Renwick, D.W.S., Jabbour, C.J. C. and Camen, M.M. (2011), State-of-the-Art and Future Directions for Green Human Resource Management: Introduction to the Special Issue, German Journal of Research in Human Resource Management, Vol. 25, No. 2, 99116.

Karatepe, O.M., Uludag, O., Menevis, I., Hadzimehmedagic, L. and Baddar. L. (2006), The effects of selected individual characteristics on frontline employee performance and job satisfaction, Tourism Management, Vol. 27, No. 4, pp. 547-560.

Kaur, H. (2011), Impact of HR factors on employee attitudes: an empirical analysis of a sample of ISO14001 EMS companies in Malaysia, Journal of Public Administration and Governance, Vol. 1, No. 1, pp. 174-196.

King, A.A. and Lenox, M.J. (2001), Lean and green? An empirical examination of the relationship between lean production and environmental performance, Production and Operations Management, Vol. 10, No. 3, pp. 244-256.

Kitazawa, S. and Sarkis, J. (2000), The relationship between ISO 14000 and continuous source reduction, International Journal of Operation and Production Management, Vol. 20, No. 2, pp. 225-248.

Klassen, R.D. and Whybark, D.C. (1999), Environmental management in operations: the selection of environmental technologies, Decision Sciences, Vol. 30, No. 3, pp. 601-631.

Kolluru, R.V. (1994), Environmental Strategies Handbook. McGraw-Hill: New York.

Lucas, M.T. (2010), Understanding Environmental Management Practices: Integrating Views from Strategic Management and Ecological Economics, Business Strategy and the Environment, Vol. 19, No. 8, pp. 543-556.

Madsen, H. and Ulhùi, J.P. (2001), Greening of human resources: environmental awareness and training interests within the workforce, Industrial Management \& Data Systems, Vol. 101, No. 2, pp. 57-65.

Mandip, G. (2012), Green HRM: People Management Commitment to Environmental Sustainability, Research Journal of Recent Sciences, Vol. 1, (ISC-2011), pp. 244-252.

Mardhatillah, A. and Rahman, W.R.A. (2011), Relationship of Spirituality at the Workplace, Job Satisfaction and Organizational Commitment with Job Performance, The Fifth Intern PG Research Colloquium: Research in Malaysia and Thailand.

Massoud, J.A., Daily, B.F. and Bishop, J.W. (2011), Perceptions of environmental management systems: An examination of the Mexican manufacturing sector, Industrial Management \& Data Systems, Vol. 111, No. 1, pp. 5-19.

May, D.R. and Flannery, L.B. (1995), Cutting waste with employee involvement teams, Business Horizon, Vol. 38, No. 5, 28-38.

McCarthy, J.M. and Goffin, R.D. (2001), Improving the validity of letters of recommendation: An investigation of three standardized reference forms, Military Psychology, Vol. 13, No. 4, pp. 199-222.

McCloskey, J. and Maddock, S. (1994), Environmental Management: Its Role in Corporate Strategy, Management Decision, Vol. 32, No. 1, pp. 27-32.

Melnyk, S.A., Sroufe, R.P. and Calantone. R. (2003), Assessing the impact of environmental management systems on corporate and environmental performance, Journal of Operations Management, Vol. 21, pp. 329-351.

Mischel, W. (1973), Toward a cognitive social learning reconceptualization of personality, Psychological Review, Vol. 80, pp. 200-213. 
Morsing, M. (2006), CSR as strategic auto-communication - on the role of external stakeholders for member identification, Business Ethics: A European Review, Vol. 15, No. 2, pp. 171182.

Motowidlo, S.J. and Van Scotter, J.R. (1994), Evidence that task performance should be distinguished from contextual performance, Journal of Applied Psychology, Vol.79, pp. 475-480.

Neto, A.S. and Jabbour, C.J.C. (2010), Guidelines for improving the adoption of cleaner production in companies through attention to nontechnical factors: A literature review, African Journal of Business Management, Vol. 4, No. 19, pp. 4217-4229.

Opatha, H.H.D.N.P. (2002), Performance Evaluation of Human Resources, Colombo: Institute of Management Sciences.

Opatha, H.H.D.N.P. (2013), Green Human Resource Management: A Simplified Introduction, Proceedings of the HR Dialogue 2013, Department of HRM, University of Sri Jayewardenepura, pp. 21-41.

Opatha, H.H.D.N.P. (2015), Organizational Behaviour, The Human Side of Work, Author Publication, Nugegoda, Colombo: Sri Lanka.

Opatha, H.H.D.N.P. and Arulrajah, A.A. (2014), Green Human Resource Management: Simplified General Reflections, International Business Research, Canadian Center of Science and Education, Vol. 7, No. 8, pp. 101-112.

Orlitzky, M., Siegel, D.S. and Waldman, D.A. (2011), Strategic Corporate Social Responsibility and Environmental Sustainability, Business \& Society, Vol. 50, No. 1, pp. 6-27.

Perron, G.M., Cote, R.P. and Duffy, J.F. (2006), Improving environmental awareness training in business, Journal of Cleaner Production, Vol. 14, No. pp. 551-562.

Poksinska, B., Dahlgaard, J.J. and Eklund, J.A.E. (2003), Implementing ISO 14000 in Sweden: motives, benefits and comparisons with ISO 9000, International Journal of Quality \& Reliability Management, Vol. 20, No. 5, pp. 585-606.

Psomas, E.L., Fotopoulos, C.V. and Kafetzopoulos, D.P. (2011), Motives, difficulties and benefits in implementing the ISO 14001 Environmental Management System, Management of Environmental Quality: An International Journal, Vol. 22, No. 4, pp. 502 - 521.

Pojasek, R.B. (2007), A framework for business sustainability, Environmental Quality Management, Vol. 17, No. 2, pp. 81-88.

Quazi, H.A. (2001), Sustainable development: integrating environmental issues into strategic Planning, Industrial Management \& Data Systems, Vol. 101, No. 2, pp. 64 - 70.

Rangarajan, N. and Rahm, D. (2011), Greening Human Resources: A survey of City- Level Initiatives, Review of Public Personnel Administration, Vol. 31, No. 3, pp. 227-247.

Ramus, C.A. (2001), Organizing support for employees: Encouraging creative ideas for environmental sustainability, California Management Review, Vol. 43, No. 3, pp. 85-103.

Ramus, C.A. (2002), Encouraging innovative environmental actions: what companies and managers must do, Journal of World Business, Vol. 37, pp. 151-164.

Ramus, C.A. and Killmer, A.B. (2007), Corporate greening through prosocial extrarole behaviours - A conceptual framework for employee motivation, Business strategy and the Environment, Vol. 16, No. 8, pp. 554-570. DOI: 10.1002/bse.504.

Ramus, C.A. and Steger, U. (2000), The roles of supervisory support behaviours and environmental policy in employee 'ecoinitiatives' at leading-edge European companies, Academy of Management Journal, Vol. 43, No. 4, pp. 605-626. doi:10.2307/1556357. 
Renwick, D.W.S., Redman, T. and Maguire, S. (2008), Green HRM: A review, process model, and research agenda, Discussion Paper Series, the University of Sheffield Management School.

Renwick, D.W.S., Redman, T. and Maguire, S. (2013), Green Human Resource Management: A Review and Research Agenda, International Journal of Management Review, Vol. 15, No. 1, pp. 1-14.

Revill, C. (2000), The 'Greening' of Personnel/Human Resource Management: An Assessment, International Journal of Applied HRM, Vol. 1, No. 3, pp. 1-30.

Rothenberg, S. (2003), Knowledge Content and Worker Participation in Environmental Management at NUMMI, Journal of Management Studies, Vol. 40, No. 7, pp. 1783-1802.

Ruiz-Quintanilla S.A., Bunge. J., Freeman-Gallant, A. and Cohen-Rosenthal, E. (1996), Employee participation in pollution reduction: a socio-technical perspective, Business Strategy and the Environment, Vol. 5, No. 3, pp. 137-144.

Russo, M.V. and Fouts, P.A. (1997), A resource based perspective on corporate environmental performance and profitability, Academy of Management Journal, Vol. 40, No. 3, pp. 534559.

Shamir, B., House, R.J. and Arthur, M.B. (1993), The motivational effects of charismatic leadership: a self-concept based theory, Organization Science, Vol. 4, No. 4, pp. 577-594.

Sharma, S., Sharma, J. and Devi, A. (2009), Corporate Social Responsibility: The Key Role of Human Resource Management, Business Intelligence Journal, Vol. 2, No. 1, pp. 205-213.

Sharma, S. and Vredenburg, H. (1998), Proactive corporate environmental strategy and the development of competitively valuable organizational capabilities, Strategic Management Journal, Vol. 19, pp. 729-753.

Sohi, R.S. (1996), The effects of environmental dynamism and heterogeneity on salespeople's role perceptions, performance and job satisfaction, European Journal of Marketing, Vol. 30, No. 7, pp. 49-67.

Strandberg, C. (2009), The Role of Human Resource Management in Corporate Social Responsibility: Issue Brief and Roadmap, Report for Industry Canada, Coro Strandberg, Principal, Strandberg Consulting.

Tinsley, S. (2002), EMS models for business strategy development, Business Strategy and the Environment, Vol. 11, pp. 376-390.

The Greening of HR Survey Results. (2009), Buck Consultants, an ACS company, a global HR consulting Firm.

Thomas, I., Sandri, O. and Hegarty, K. (2010), Green Jobs in Australia: A Status Report, Sustainability, Vol. 2, pp. 3792-3811. doi:10.3390/su2123792.

Tranfield, D., Denyer, D. and Smart, P. (2003), Towards a methodology for developing evidence-informed management knowledge by means of systematic review, British Journal of Management, Vol. 14, No. 3, pp. 207-222.

United Nations Environment Programme. (2008), UNEP background paper on green jobs. Nairobi. Retrieved 5-11-2013, from http://grist.files.wordpress.com/2008/02/greenjobsbackground-paper-18-01-08.pdf.

Valente, M. (2012), Theorizing Firm Adoption of Sustaincentrism, Organizational Studies, Vol. 33, No. 4, pp. 563-591.

Wagner, M. (2011), Environmental Management Activities and Sustainable HRM in German Manufacturing Firms - Incidence, Determinants, and Outcomes, German Journal of Research in Human Resource Management, Vol. 25, No. 2, pp. 157-177. 
Wee, Y.S. and Quazi, H.A. (2005), Development and validation of critical factors of environmental management, Industrial Management Data System, Vol. 105, No. 1, pp. 96114.

Wehrmeyer, W. (1996), Greening People: Human Resource and Environmental Management, New York: Greenleaf.

Wehrmeyer, W. (1997), Going green is good for businesses and for HR staff, Management Development Review, Vol. 10, No. 1, pp. 30-31.

Wernerfeldt, B. (1984), A resource-based view of the firm, Strategic Management Journal, Vol. 5, No. pp. 171-180.

Wever, G.H. and Vorhauer, G.F. (1993), Kodak's framework and assessment tool for implementing TQEM, Total Quality Environmental Management, pp. 19-30.

www.triplepundit.com, Walmart's Green Human Resources Best Practices _ TriplePundit.htm) (Accessed 7/8/2012).

Yee, S.B., Eze, U.C. and Gan, G.G.G. (2010), Factors Influencing Environmentally Responsible Manufacturing System Implementation in a Manufacturing Firm. The $11^{\text {th }}$ Asia Pacific Industrial Engineering and Management Systems Conference.

Yousef, D.A. (2000), Organizational commitment: a mediator of the relationships of leadership behavior with job satisfaction and performance in a non-western country, Journal of Managerial Psychology, Vol. 15, No. 1, pp. 6-24.

Zoogah, D.B. (2011), The Dynamics of Green HRM Behaviors: A Cognitive Social Information Processing Approach, German Journal of Research in Human Resource Management, Vol. 25, No. 2, pp. 117-139.

Zutshi, A. and Sohal, A.S. (2005), Integrated management system: The experiences of three Australian organizations, Journal of Manufacturing Technology Management, Vol. 16, No. 2, pp. $211-232$.

Zutshi, A. and Sohal, A.S. (2004), Adoption and Maintenance of Environmental Management Systems: Critical Success Factors, Management of Environmental Quality: An International Journal, Vol.15, No. 4, pp. 399-419. 